\title{
Energy Consumption and Sectorial Value Addition on Economic Growth in Nigeria
}

\author{
Udo Emmanuel Samuel ${ }^{1, *}$, Idamoyibo Hwerien Rosemary ${ }^{2}$, Victor Inim ${ }^{3}$, Akpan Jack Ededem ${ }^{4}$, \\ Victor Ndubuaku ${ }^{5}$ \\ ${ }^{1}$ Department of Banking and Finance, University of Nigeria Enugu, Nigeria \\ ${ }^{2}$ Department of Accounting, Ignatius Ajuru University of Education, Port Harcourt, Nigeria \\ ${ }^{3}$ Department of Accounting, Nile University of Nigeria, Nigeria \\ ${ }^{4}$ Department of Banking and Finance, University of Nigeria Enugu, Nigeria \\ ${ }^{5}$ Federal College of Agriculture Ishiagu, Nigeria
}

Received November 14, 2020; Revised December 25, 2020; Accepted January 28, 2021

\section{Cite This Paper in the following Citation Styles}

(a): [1] Udo Emmanuel Samuel, Idamoyibo Hwerien Rosemary, Victor Inim, Akpan Jack Ededem, Victor Ndubuaku, "Energy Consumption and Sectorial Value Addition on Economic Growth in Nigeria," Universal Journal of Accounting and Finance, Vol. 9, No. 1, pp. 74 - 85, 2021. DOI: 10.13189/ujaf.2021.090108.

(b): Udo Emmanuel Samuel, Idamoyibo Hwerien Rosemary, Victor Inim, Akpan Jack Ededem, Victor Ndubuaku, (2021). Energy Consumption and Sectorial Value Addition on Economic Growth in Nigeria. Universal Journal of Accounting and Finance, 9(1), 74 - 85. DOI: 10.13189/ujaf.2021.090108.

Copyright $\bigcirc 2021$ by authors, all rights reserved. Authors agree that this article remains permanently open access under the terms of the Creative Commons Attribution License 4.0 International License

\begin{abstract}
This study investigates the co-integrating and causal link between energy consumption and economic growth in three economic sectors of agriculture, manufacturing, and service sectors in Nigeria. Through the multivariate framework and quarterly data from $2000 Q_{1}-2018 Q_{4}$. The ARDL bounds test approach, and Error Correction Model are the key techniques of analysis, and the Clemente-Montanes-Reyes unit root approach for structural breaks in the series. Findings revealed estimated billing system, and energy demand-supply gap as factors negatively influencing energy distribution and consumption in various sectors of the economy. The results also revealed a co-integrating relationship between economic growth and sectorial value creation. The results also revealed a bidirectional causality between liquefied natural gas and energy consumption and a unidirectional causality between economic growth and petroleum oil consumption. On the contrary, there is a non-causal relationship between the service and agricultural sectors. Sufficient energy distribution and consumption stir economic growth through value additions in the agricultural, manufacturing, and service sectors. The study recommends a review of the billing system, pricing framework, and policies to support, value creation, and addiction in Nigeria.
\end{abstract}

Keywords Energy Consumption, Economic Growth, Petroleum Oil, Gas, Co-Integration, Granger Causality, ECM

JEL Classifications: C320, O13, O130, O44P28, Q430

\section{Introduction}

Energy is an integral element in human civilization, the importance of energy has increased geometrically during the last decade, its undoubtedly a fulcrum for sustainable business, economic and financial growth, globally and especially for emerging economies like Nigeria. Nations with a higher per capita energy consumption and distributions are considered economically robust and industrialized vice-versa those with low levels of consumption and distribution. According to the classical school of thought, land, labour, and capital impact growth and output significantly (Enu and Havi [1]).

Other transitional inputs are fairly disregarded in the growth theories of energy supply-demand, and the pricing framework on output and economic growth. Energy comprises hydroelectric, geothermal, natural gas, lignite, coal, biomass, and in recent times solar, and wind energy among others. Energy efficiency and distribution increase 
revenue generation through small business development, sectoral output capacity, and utility cost reduction. Nigeria ranks as one of the largest and oldest oil producers in Africa and the $6^{\text {th }}$ largest oil-producing country globally with around 37 billion barrels of oil and 47.2 billion cubic meters $(\mathrm{bcm})$ of gas. The average production capacity is about 2.05 million per day in 2019 accounting for more than $20.4 \%$ of total oil production in Africa in 2019 and gross domestic product contribution of over $91.2 \%$ of all export value and $8.73 \%$ single sector contribution in Nigeria.

Notwithstanding, the vast sources of energy available in Nigeria, the gap between energy production, distribution, and consumption are still the major challenges affecting economic growth and product value creation and addition. The Nigerians total population is estimated at 200 million in 2020 , about $55-60 \%$ of the rural populace lack access to electricity, while only, $40-45.5 \%$ of urban dwellers have access to electricity but at a very high cost, (Figure 1).

Such is evident in the gap between installation and actual operational capacity output not exceeding 4,000 MegaWatt (MW) per hour averaging less than $40 \%$. Install capacity between $2014-2015$ stood at $12,522 \mathrm{MW}$ from the 25 power stations, with an average available capacity of $7,141 \mathrm{MW}$ on the average operational capacity of $3,879 \mathrm{MW} / \mathrm{hr}$ as against the estimated demand of 10,000MW per day (CBN Annual Reports, [3]). The manufacturing sector electricity consumption rate represents $48.2 \%$, while other sector's consumption rate falls between $25.3 \%-47.3 \%$. Coal, petroleum, natural gas, nuclear fuels, and biomass contributes about 25\%-35\% consumption rate. Energy production and consumption in Nigeria from 1980-2019 fluctuate between 2\%-4.0\% respectively (Figure 2).

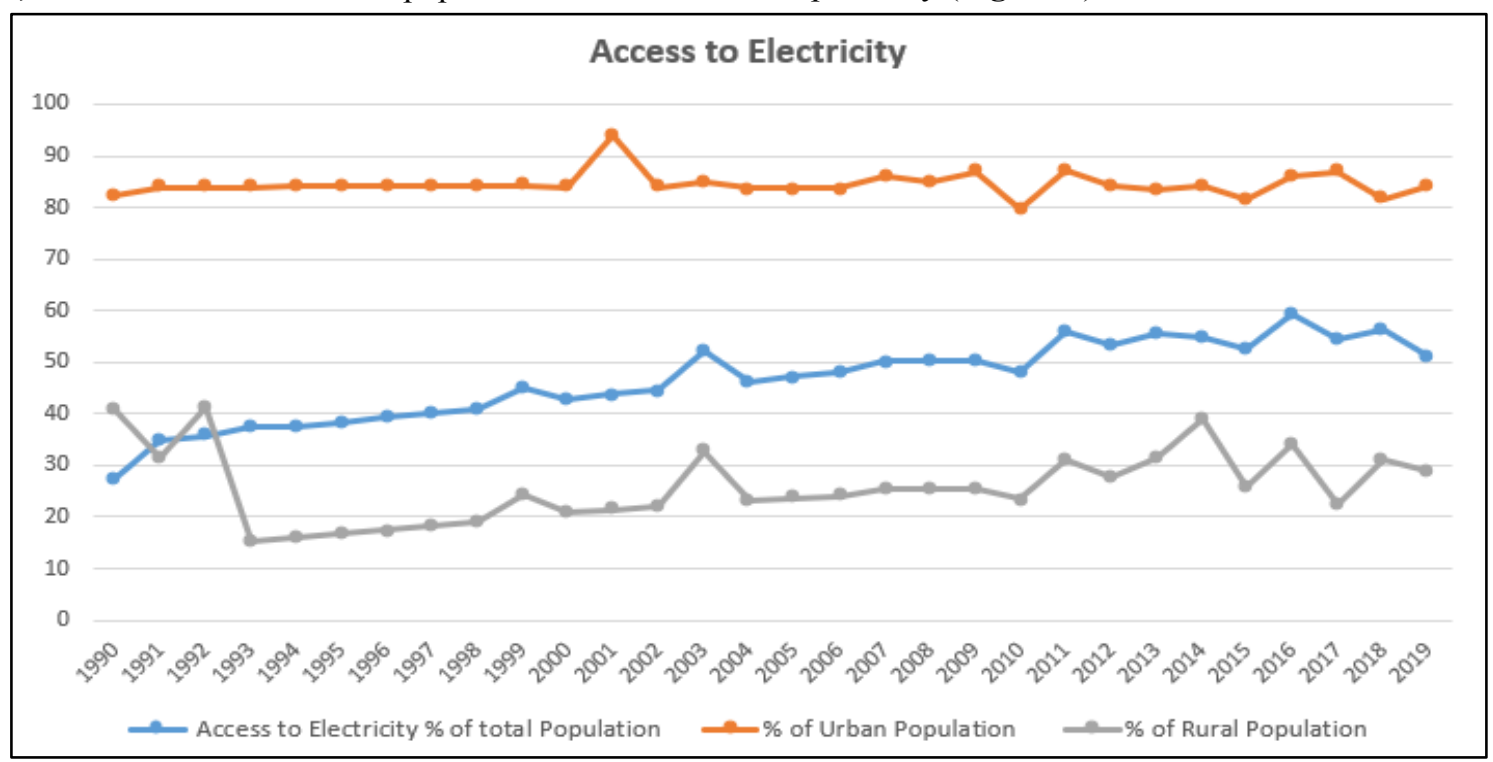

Source: (Computed from World Development Indicator Database [2])

Figure 1. Access to Electricity \% of the Population, Urban and Rural Dwellers

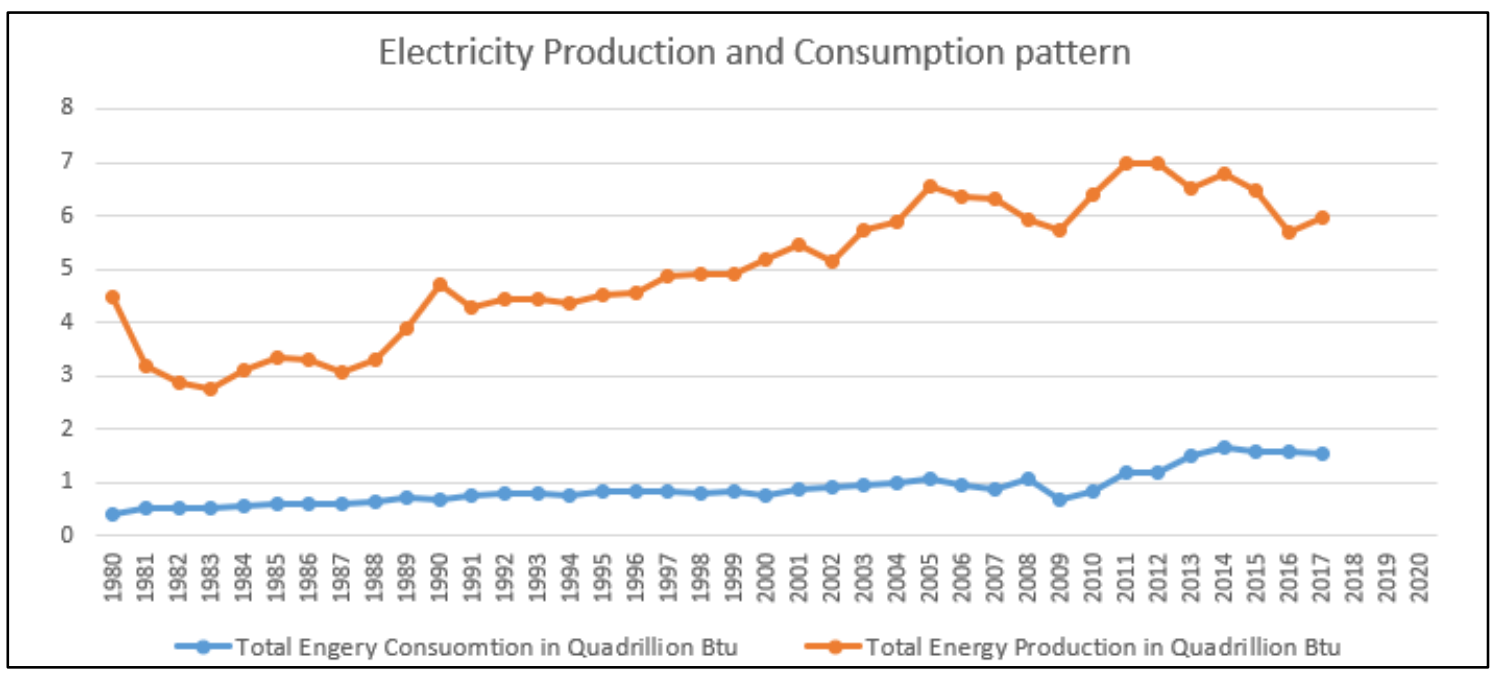

Source: (Computed from World Development Indicator Database [2])

Figure 2. Electricity Production and Consumption Patterns in Nigeria. 
The ripple effect of poor access to electricity, for production, is evident in the poor and constant fluctuation in industrial, agricultural, and service sectors share contribution to GDP in the last 10year of 2009-2019. Specifically, in the industrial and service sectors between 2015-2017 (see Table 1).

Table 1. Share of the value-added of the three sectors in GDP (\%) in Nigeria

\begin{tabular}{|c|c|c|c|}
\hline Year & Agriculture & Industry & $\begin{array}{c}\text { Services } \\
\text { (commercial \& } \\
\text { public) }\end{array}$ \\
\hline 2009 & 26.75 & 21.24 & 50.98 \\
\hline 2010 & 23.89 & 25.32 & 50.79 \\
\hline 2011 & 22.23 & 28.28 & 49.24 \\
\hline 2012 & 21.86 & 27.07 & 50.19 \\
\hline 2013 & 20.76 & 25.74 & 52.37 \\
\hline 2014 & 19.99 & 24.64 & 54.15 \\
\hline 2015 & 20.63 & 20.16 & 58.12 \\
\hline 2016 & 20.98 & 18.17 & 59.79 \\
\hline 2017 & 20.85 & 22.32 & 55.8 \\
\hline 2018 & 21.2 & 25.73 & 52.02 \\
\hline 2019 & 21.91 & 27.38 & 49.73 \\
\hline
\end{tabular}

Source: (Computed from World Development Indicator Database [2])

Electricity consumption in the industrial, agricultural, and service sectors in Nigeria in the last decade has been on constant decease especially in the industrial sector, as a result of the estimated billing system, vandalization of electrical facilities, over-dependence on generating set, and the frequent collapse of the national grip among others (Figure 3).

Similarly, the telecommunications companies in Nigeria (MTN NG, Airtel Nigeria, Globacom, and 9mobile) spend about $\$ 100$ million on diesel fuel to provide electricity and keep their telecommunication mast operational. MTN, controls a market share of $43 \%$, spending about $\$ 40$ million annually to supply its base stations electricity for $19 \mathrm{hrs}$ a day, 9mobile market share of (15\%) Airtel Nigeria (20\%), and Globacom (21\%) on average spends $\$ 35$ million to $\$ 40$ million to run its base stations.

The growth of these economic sectors largely depends on stable, efficient, affordable, and accessible energy distribution and consumption. Figure 3 shows the share of electricity consumption by each sector (agriculture, industry, and service) in Nigeria as a percentage of total electricity consumption. Primary energy consumption in Nigeria consists of $55 \%$ of petroleum and other liquid gas, $42 \%$ of natural gas, $3 \%$ of renewable, and $0.0 \%$ coal.

In the bid to ensure stable, efficient, affordable, and accessible energy production, distribution, and consumption to drive economic growth successive governments in Nigeria developed diverse policy structures, and frameworks such as the; 1972 import substitution/indigenization policy, 1986 Structural Adjustment Program (SAP), the 2005 Electricity Power Sector Reform Act (EPSRA), and the 2007 National Integrated Industrial Development (NIID) blueprint among others. Regardless of these policy structures, available statistics revealed the gap between energy demand and supply affecting export goods value chain effect, high production cost, crowding out of 30\%-35\% domestic firms, and multinational firms to neighboring countries of Ghana and South Africa with a relatively stable power supply. The increase in carbon dioxide emissions in Nigeria can be accredited to dependence on natural gas and oil sources in electricity generation (Karanfil, [4]).

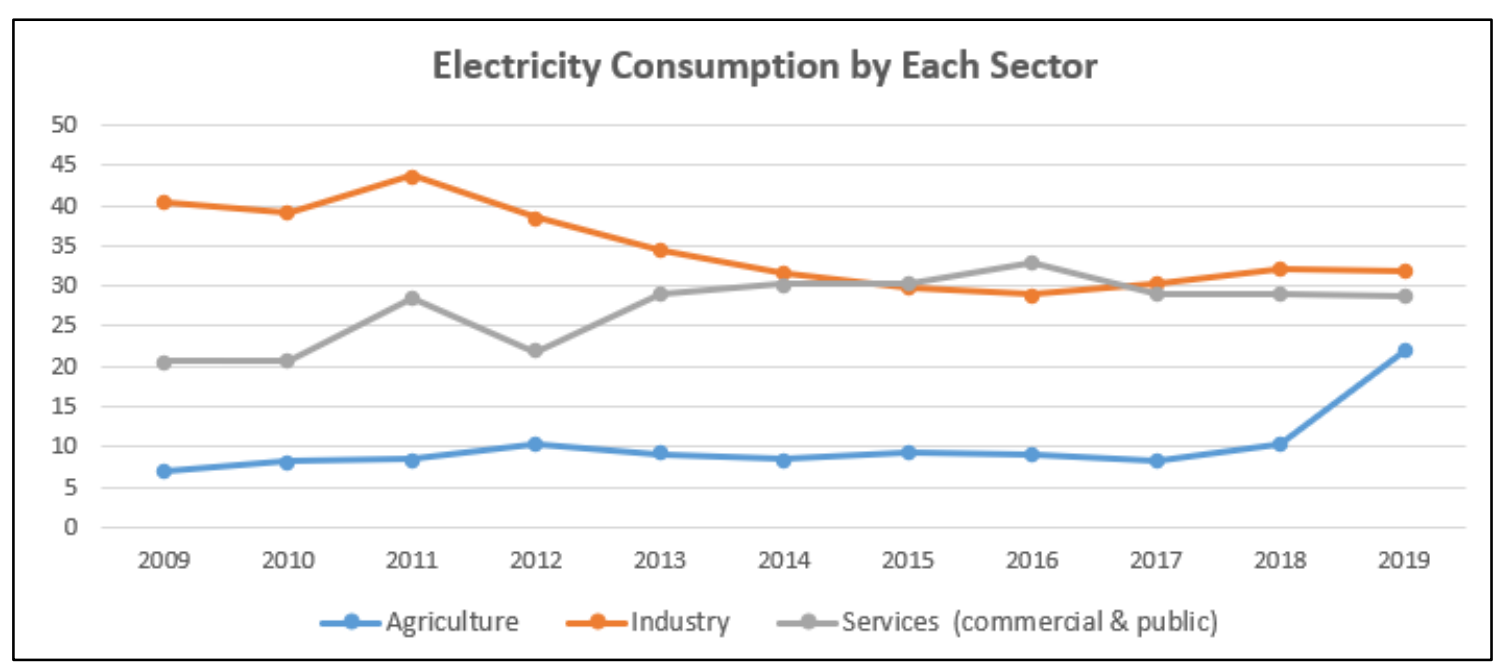

Source: (Computed from World Development Indicator Database [2])

Figure 3. Electricity Consumption by Each Sector 
The geometric increase in carbon dioxide emissions makes it necessary for the government to bridge the gap between energy demand-supply, and reduce the polluting emissions without adversely affecting the economic growth either at the aggregate level or the sectoral levels. The objective of the study is to investigate the co-integrating and causal link between electricity consumption on economic growth and sectoral value creation and addition in three economic sectors, of agriculture, industrial, and services sectors.

This study contributes to the extant literature in two parts; firstly, to examine the causal and co-interning relationship between electricity consumption, economic growth, and sectoral value creation and addition in Nigeria.

Secondly, the present study comprises quarterly data period $2000 Q_{1}-2018 Q_{4}$. The study employs the ARDL bounds test approach, Error Correction Model, and Granger causality to explore the co-integrating and causal relationship. Also, the Clemente-Montanes-Reyes unit root for structural breaks in the series.

\section{Literature Review}

Studies on energy consumption and economic growth in the last decades in single and cross-countries have reported diverse results due to country-specific heterogeneous factors of climatic conditions, institutional structural challenges, pricing systems, and stages of economic growth (Enu and Havi [1]). These studies concluded the existence of four hypotheses: (1) conservation hypothesis; (2) growth hypothesis; (3) feedback hypothesis, and (4) neutrality hypothesis, as a result of diverse periods, methodologies, and various energy consumption variables employed (Laurine, Ngundu, and Kupeta [5]). Empirical evidence from Molem, and Ndifor [6]); Chinedu, Daniel, and Ezekwe, [7]); Belaid, and Youssef [8]); Mawejje, and Mawejje [9]); Sharif, Jammazi, Raza, Shahzad, [10]); Laurine, Ngundu, and Kupeta [5]); Carfora, Pansini, and Scandurra, [11]) reported a unidirectional causality, between energy consumption and economic growth. Support the growth hypothesis of energy-led growth "unidirectional causality" energy availability, affordability, and accessibility influences economic growth, value creation, factors of production (labor and capital), social and technological advancement.

The conservation hypothesis supports the unidirectional causality from economic growth to energy consumption. Economic stability increases the demand for energy for production and consumption for industrial use and storage (Yu and Choi, [12], Ghosh [35] Halicioglu [36] Belaid, and Youssef, [8]).
Similarly, Karanfil, [4]; Enu and Havi [1]; Ibrahiem [13]; Osman, Gachino, and Hoque [14]; Ahmad, Zhao, Shahbaz, Bano, Zhang, and Wang [15; Adegboye and Babalola [16]; Ibrahiem [17] Sarwar, Chen, and Waheed [18]; (Wang et al., [15] observed a bidirectional causality between energy consumption and economic growth supporting the feedback hypothesis of interdependence between the variables. Aminu and Aminu, [19]; Bah, and Azam [20]; Egbichi, Ojamaliya, Okafor, Godwin, and Oluwapelumi [21], and Odhiambo, [22] reported a non-causal relationship supporting the neutrality hypothesis. Energy consumption and economic growth are not mutually dependent on each other. The energy conservation policies may have no adverse effect on economic growth. A summary of these studies is shown in (Table 2).

Nathan and Liew [37] in Cambodia, examined the causal link between energy consumption and economic growth in various sectors. Findings supported mixed results of unidirectional causality running from energy consumption to agricultural, industrial, and transportation sectors, and unidirectional causality from the services sector to energy consumption. Country studies ignored the heterogeneous factors that are inherent in specific countries. Therefore, a single-country study would explain the effect and causality in terms of each countries stages of economic and energy sector development among others.

\section{Energy Sector in Nigeria}

Energy sufficiency stirs global economic growth through renewable and non-renewable sources to stir production, job creation, and export goods value chain effect among others.

Non-renewable energy is the prevailing form of energy largely consumed in Nigeria. Crude oil accounts for over $79 \%$ of commercial energy consumption in Nigeria and is a major source of foreign earnings. The lack of operational energy infrastructures has led to the flaring of about $40 \%$ of the natural gas in Nigeria, accounting for about $20 \%$ of all gas flared globally.

The energy demand-supply gap has not only destabilized economic industrialization in Nigeria but has also truncated the achievement of the Millennium Development Goals (MDGs) and Sustainable Development Goals (SDGs) in Nigeria (Babanyara and Saleh, [23]). According to the United Nations Economic Commission for Africa, insufficient energy supply in Sub-Saharan Africa hinders economic growth and poverty alleviation programs of the government, with more than $67.8 \%$ of the rural and the urban dwellers in extreme poverty living below $\$ 2$ per day and $23.5 \%$ in moderate poverty living below $\$ 3$ per day without access to modern energy services for production, creativity and economic growth (Adegboye \& Babalola, [16]). 
Over $70.5 \%$ of the rural dwellers in Nigeria depend on firewood consuming over 50 million tonnes of firewood annually that surpasses the replenishment rate through various afforestation programs of the government. The rate of deforestation is about 350,000 ha/year. The rural areas are generally inaccessible due to the poor road network, little or no access to conventional energy such as electricity and petroleum products. The rural areas in Nigeria account for about $43.5 \%$ of micro, small, medium scale businesses. Petroleum products such as kerosene and gasoline are purchased in the rural areas at prices $150 \%$ above their official pump prices. Despite the huge investments and policy framework made in the power sectors over the years, there has been little or non-significant improvement in the supply of electricity in Nigeria. Notwithstanding the poor energy sector performance below par, there is a steady increase in economic growth over the years.

\subsection{Theoretical Framework}

Economic growth globally consists of people "labour force, energy, and matter. There is no economic growth and sectorial value addition and creation without the expense of energy. Energy is an integral factor in driving effective and efficient economic activities. Thus, energy influences and measures the level of economic growth through production and value creation and addition than product outputs.

The theoretical underpinning selected for this study includes; the physical theory of economic growth propounded by Kardashev (1964), which states that energy is vital for economic reproducibility and growth. The economic benefits of energy availability and accessibility on production cannot be overemphasis by natural scientists and ecological economists (Okorie and
Manu [25]).

According to the proponents of the biophysical and theory of economic growth, energy is the only factor of production (Stern [33]). On the contrary, the classical (mainstream) economists explicitly ignored energy as a factor of production due to land imposed limitations on economic activities, in the agricultural sector. Energy is incorporated implicitly into the economy through the recognition of land as a factor in production in the agricultural sector (Babanyara and Saleh, [23]).

The neutrality hypothesis propounded by $\mathrm{Yu}$ and Choi, [12] states that energy and economic growth are not mutually dependent on each other. Energy conservation policies may have a neutral or minimal effect on economic growth. The ecological and mainstream economists recognize petroleum oil and other sources of energy as economic growth and industrial value addition as intermediary input while energy, labour, and land as primary factors of production (Aghion and Howitt, [24]).

This study adopted the unifying mainstream and ecological energy/growth model to explored the causal and co-integrating relationship between energy consumption, economic growth, and sectorial value addition in Nigeria using the conservation hypothesis; growth hypothesis; feedback hypothesis, and neutrality hypothesis.

The thermodynamics law provides the rationale for the model selection partly to the fact that energy/electricity is indispensable in all economic production thus supporting the criticism against mainstream energy/growth models that ignore energy in the production process. Similarly, energy/growth theories tries to explain growth exclusively as a function of energy, while disregarding the impact of information, knowledge, and institutions, on growth. Institutions significantly influence the link between energy and growth. 


\section{Empirical Review}

Table 2. Summary of Empirical Reviews

\begin{tabular}{|c|c|c|c|}
\hline Author and Year & Scope & Methodology & Result \\
\hline \multicolumn{4}{|c|}{ Studies Supporting "Unidirectional Causality Hypothesis" } \\
\hline Adegboye and Babal [16] & Nigeria (1981-2018 & ARDL and ECM & Energy $\rightarrow$ Economic growth \\
\hline Tahar [26] & Morocco & Granger causality test & Energy $\rightarrow$ Economic growth \\
\hline Belaid, and Youssef, [8] & Algeria 1980-2012 & $\begin{array}{l}\text { Vector Error Correction } \\
\text { Model }\end{array}$ & $\begin{array}{c}\text { Economic growth } \rightarrow \text { renewable electricity } \\
\text { Economic growth } \rightarrow \text { nonrenewable electricity }\end{array}$ \\
\hline Mawejje, and Mawejj [9] & $\begin{array}{c}\text { Uganda Q12005- } \\
\text { Q12015 } \\
\end{array}$ & Granger causality & $\begin{array}{l}\text { Electricity } \rightarrow \text { industry (long run) } \\
\text { Service } \rightarrow \text { electricity (short-run) }\end{array}$ \\
\hline Sharaf [27] & Egypt 1980-2012 & $\begin{array}{l}\text { Toda and Yamamoto } \\
\text { Granger causality test }\end{array}$ & Economic growth $\rightarrow$ electricity \\
\hline $\begin{array}{l}\text { Sharif, Jammazi, Raza, } \\
\text { and., Shahzad [10] }\end{array}$ & $\begin{array}{c}\text { Singapore 1983- } \\
2016 \text { (monthly data) }\end{array}$ & Wavelet approach & $\begin{array}{c}\text { Electricity } \rightarrow \text { Economic growth (long run) } \\
\text { Electricity } \leftrightarrow \text { Economic growth (medium run) }\end{array}$ \\
\hline \multicolumn{4}{|c|}{ Studies Supporting the "No Causal Relationship Hypothesis" } \\
\hline Aminu, and Aminu, [19] & Nigeria (1980-2011) & $\begin{array}{l}\text { Granger causality } \\
\text { test, impulse response, and } \\
\text { variance decomposition } \\
\text { analysis }\end{array}$ & $\begin{array}{l}\text { No causal relationship between energy } \\
\text { consumption and economic growth }\end{array}$ \\
\hline Bah, and Azam, [20] & $\begin{array}{l}\text { South Africa } 1971- \\
2012 \\
\end{array}$ & $\begin{array}{c}\text { Toda and Yamamoto } \\
\text { Granger causality test }\end{array}$ & $\begin{array}{c}\text { No causality relationship between energy } \\
\text { consumption and economic growth }\end{array}$ \\
\hline \multicolumn{4}{|c|}{ Studies Supporting the "Bidirectional Hypothesis" } \\
\hline Ibrahiem [17] & Egypt (1971-2013) & $\begin{array}{c}\text { Johansen cointegration } \\
\text { approach, and vector error } \\
\text { correction model } \\
\end{array}$ & Real output $\leftrightarrow$ Electricity Consumption. \\
\hline $\begin{array}{c}\text { Ahmad, Zhao, Shahbaz, } \\
\text { Bano, Zhang, Wang, Liu, } \\
{[15]} \\
\end{array}$ & India 1971-2014 & Vector error correction model & Electricity $\leftrightarrow$ Economic Growth \\
\hline $\begin{array}{c}\text { Sarwar, Chen, and Waheed, } \\
{[18]}\end{array}$ & $\begin{array}{c}210 \text { countries } \\
1960-2014 \\
\end{array}$ & $\begin{array}{c}\text { Panel vector error correction } \\
\text { model }\end{array}$ & Electricity $\leftrightarrow$ Economic Growth \\
\hline $\begin{array}{l}\text { Osman, Gachino, and } \\
\text { Hoque [14] }\end{array}$ & $\begin{array}{c}\text { Gulf Corporation } \\
\text { Council } \\
\text { Countries 1975-2012 } \\
\end{array}$ & $\begin{array}{c}\text { Panel VAR Granger causality } \\
\text { Test }\end{array}$ & Electricity $\leftrightarrow$ economic growth \\
\hline \multicolumn{4}{|c|}{ Studies Supporting the "Neutrality Hypothesis" } \\
\hline $\begin{array}{l}\text { Ugwoke, Dike, and Elekwa } \\
{[28]}\end{array}$ & Nigeria (1980-2014) & $\begin{array}{l}\text { Double-log linear } \\
\text { formulation. }\end{array}$ & $\begin{array}{l}\text { A negative relationship between electricity } \\
\text { consumption, trade openness, and industrial } \\
\text { production }\end{array}$ \\
\hline Molem, and Ndifor, [6] & $\begin{array}{l}\text { Cameroon } \\
(1980-2014)\end{array}$ & $\begin{array}{l}\text { Generalized Method of } \\
\text { Moments technique }\end{array}$ & $\begin{array}{l}\text { A positive relationship between energy } \\
\text { consumption on economic growth }\end{array}$ \\
\hline $\begin{array}{l}\text { Chinedu, Daniel, \& } \\
\text { Ezekwe, [7] }\end{array}$ & Nigeria (1980-2017) & $\begin{array}{c}\text { Engle-Granger Co-integration } \\
\text { test, error-correction } \\
\text { mechanism } \\
\end{array}$ & $\begin{array}{l}\text { A positive relationship between energy } \\
\text { consumption on economic growth }\end{array}$ \\
\hline
\end{tabular}

Source: Authors Computation (2020) 


\section{Methodology}

The multivariate Granger-causality model, Autoregressive Distributed Lag (ARDL), and the Clemente-Montanes-Reyes unit root test for structural breaks are employed in this study with quarterly data covering the period 2000Q-2018Q, obtained from the Central Bank of Nigeria and World Bank Development Indicators. Energy consumption in this study is disaggregated into petroleum oil, liquified natural gas, and electricity. The variables are transformed to their natural logarithmic form.

\section{Model Expression}

The linear model expression:

$$
\begin{aligned}
& \text { RGDP }=\beta_{0}+\beta_{1} \text { ELECT }+\beta_{2} \text { LIQOIL }+\beta_{3} \text { PETOIL }+\beta_{4} \text { CAFM } \\
&+\beta_{5} \text { LABF }+\beta_{6} \text { AGRI }+\beta_{7} \text { MANU }+\beta_{8} \text { SERV } \mu \\
& \text { ELECT }=\beta_{0}+\beta_{1} \text { AGRI }+\beta_{2} \text { MANU }+\beta_{3} \text { SERV }+\mu
\end{aligned}
$$

\section{Symmetrical ARDL model}

The bounds test procedure expression:

$$
\begin{aligned}
& \Delta \mathrm{RGDP}_{\mathrm{t}}=\beta_{0}+\sum_{i=1}^{m} \quad \beta_{1}{ }^{\mathrm{i}} \Delta \mathrm{ELECT}_{\mathrm{t}-\mathrm{i}}+\sum_{j=0}^{n} \\
& \beta_{2}{ }^{i} \Delta \text { LIQOIL }_{\mathrm{t}-\mathrm{j}}+\sum_{j=0}^{n} \quad \beta_{3}{ }^{\mathrm{i}} \Delta \text { PETOIL }_{\mathrm{t}-\mathrm{j}}+\beta_{4} \text { RGDP }_{\mathrm{t}-1}+ \\
& \beta_{5} \text { LIQOIL }_{\mathrm{t}-1}+\beta_{6} \text { PETOIL }_{\mathrm{t}-1}+\mu_{\mathrm{t}} \\
& \Delta \text { ELECT }_{\mathrm{t}}=\beta_{0}+\sum_{i=1}^{m} \quad \beta_{1}{ }^{\mathrm{i}} \Delta \mathrm{AGRI}_{\mathrm{t}-\mathrm{i}}+\sum_{j=0}^{n} \\
& \beta_{2}{ }^{\mathrm{i}} \Delta \mathrm{MANU}_{\mathrm{t}-\mathrm{j}}+\sum_{j=0}^{n} \quad \beta_{3}{ }_{3}{ } \Delta \mathrm{SERV}_{\mathrm{t}-\mathrm{j}}+\beta_{4} \mathrm{AGRI}_{\mathrm{t}-1}+ \\
& \beta_{5} \text { MANU }_{\mathrm{t}-1}+\beta_{6} \mathrm{SERV}_{\mathrm{t}-1}+\mu_{\mathrm{t}} \\
& \mathrm{H}_{0}=\beta_{1}=\beta_{2}=\beta_{3}=0 \text { (there is no co-integration) } \\
& \mathrm{H}_{1}=\beta_{1}=\beta_{2}=\beta_{3}=0 \text { (there is co-integration) }
\end{aligned}
$$

\section{Decision Rule}

1. If the F-statistics falls above the upper bound critical value, there is a (co-integration)

2. If the F-statistics falls below the lower bound, there is (no co-integration) and

3. If the F-statistics falls within the two bounds the result is (inconclusive).

The Error Correction Model (ECM) measures the speed

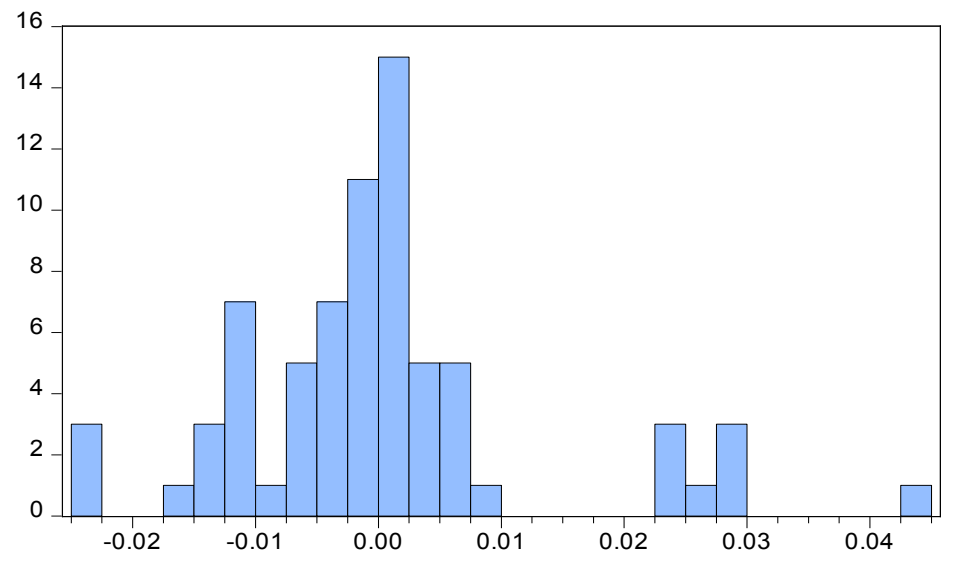

Figure 4. Variables description and characteristics. of convergence from disequilibrium cause in the short-run back to the long-run equilibrium. After establishing a long-run relationship. The ECM provides the short-run coefficient without losing the long-run information and specified as:

$$
\begin{aligned}
& \Delta \mathrm{RGDP}_{\mathrm{t}}=\beta_{0}+\sum_{i=1}^{m} \quad \beta_{1}{ }^{\mathrm{i}} \Delta \mathrm{ELECT}_{\mathrm{t}-\mathrm{i}}+\sum_{j=0}^{n} \quad \beta_{2}{ }^{\mathrm{i}} \Delta \mathrm{LIQOIL}_{\mathrm{t}-\mathrm{j}} \\
& +\sum_{j=0}^{n} \quad \beta_{3}{ }^{i} \Delta \text { PETOIL }_{\mathrm{t}-\mathrm{j}}+\delta \mathrm{ECT}_{\mathrm{t}-1}+\mu_{\mathrm{t}} \\
& \Delta \mathrm{ELECT}_{\mathrm{t}}=\beta_{0}+\sum_{i=1}^{m} \quad \beta_{1}{ }^{\mathrm{i}} \Delta \mathrm{AGRI}_{\mathrm{t}-\mathrm{i}}+\sum_{j=0}^{n} \quad \beta_{2}{ }^{\mathrm{i}} \Delta \mathrm{MANU}_{\mathrm{t}-\mathrm{j}} \\
& +\sum_{j=0}^{n} \quad \beta_{3}{ }^{i} \Delta \mathrm{SERV}_{\mathrm{t}-\mathrm{j}}++\delta \mathrm{ECT}_{\mathrm{t}-1}+\mu_{\mathrm{t}}
\end{aligned}
$$

Where:

$\beta_{0}=$ Constant term,

$\beta_{1}-\beta_{4}=$ Regression coefficient and $\mu=$ Error Term.

RGDP $=$ Real Gross Domestic Product is measured as (real GDP $=$ GDP at Market Prices -indirect taxes net of subsidies)

ELECT $=$ Electric power consumption

LIQOIL = liquefied natural gas consumption

PETOIL $=$ Petroleum oil consumption

AGRI $=$ agriculture sector value addition

MANU = manufacturing sector value addition and

SERV = service sector value addition (small business development)

The apriori expectations of the explanatory variables are as expressed as $\beta_{0}, \beta_{1}, \beta_{2}, \beta_{3}, \beta_{4}>0$;

\section{Results and Discussions}

Preceding the model estimations and diagnostic tests an array of the pre-estimation tests was conducted on the series to confirm their stationarity properties.

\section{Pre-Test}

Figure (4) describes the aggregated averages of the mean, median, and standard deviation, measuring the spread and variation. Skewness measures the degree of symmetry and kurtosis measures the peakedness. The Kurtosis is ( $>3)$, the variables are leptokurtic. The dataset produces more outliers than a normal distribution. The JB $\mathrm{P}$-value is $>5 \%$.

\begin{tabular}{|lr|}
\hline \multicolumn{2}{|l|}{ Series: Residuals } \\
Sample 2001Q1 2018Q4 \\
Observations 72 \\
Mean & $-3.97 \mathrm{e}-15$ \\
Median & -0.001818 \\
Maximum & 0.043590 \\
Minimum & -0.023463 \\
Std. Dev. & 0.012324 \\
Skewness & 1.134201 \\
Kurtosis & 5.056502 \\
& \\
Jarque-Bera & 28.12454 \\
Probability & 0.000001 \\
\hline
\end{tabular}




\section{Unit Root Test}

The unit root test was conducted using Augmented Dickey-Fuller (ADF) [29] and Phillips and Perron, (PP) [30] unit root technique to examine the stationarity properties of the variables. The null hypotheses of the ADF and PP tests are that the series has a unit root.

\section{The model expression:}

$$
\Delta \mathrm{y}_{\mathrm{t}-1}=\alpha 0+\lambda \mathrm{y}_{\mathrm{t}-1}+\alpha_{2 \mathrm{t}}+\Sigma_{\mathrm{i}=2}^{\mathrm{p}} \beta_{\mathrm{j}} \Delta \mathrm{y}_{\mathrm{t}-1}+\mu_{\mathrm{t}} .
$$

Where $\mathrm{y}=$ dependent variable,

$$
\begin{gathered}
\mathrm{t}=\text { trend, } \\
\mathrm{a}=\text { intercept, } \\
\mu \mathrm{t}=\text { white noise and } \\
\mathrm{p}=\text { lag level. }
\end{gathered}
$$

Table (3) shows the stationarity order of the variables at I (1) and I (0) integration. A combination of the I (1) and I (0) order of integration provides the theoretical underpinning for the adoption of the ARDL model. The

\begin{tabular}{|c|c|c|c|c|c|c|}
\hline Variables & Test & Level@ @ $\%$ & Inference & Test & $1^{\text {st }}$ Difference @ 5\% & Inference \\
\hline \multirow{2}{*}{ RGD } & $\mathrm{ADF}$ & $-3.457(-2.032) * * *$ & \multirow{2}{*}{ Stationary } & $\mathrm{ADF}$ & $-4.925(-3.150)^{* * *}$ & \multirow{2}{*}{ Stationary } \\
\hline & $\mathrm{PP}$ & $-3.448(-2.036) * * *$ & & PP & $-5.924(-3.159)^{* * *}$ & \\
\hline \multirow{2}{*}{ ELECT } & $\mathrm{ADF}$ & $-3.527(-1.209)^{* * *}$ & \multirow{2}{*}{ Stationary } & $\mathrm{ADF}$ & $-4.902(-3.401)^{* * *}$ & \multirow{2}{*}{ Stationary } \\
\hline & $\mathrm{PP}$ & $-3.560(-6.199)^{* * *}$ & & PP & $-4.813(-3.590)^{* * *}$ & \\
\hline \multirow{2}{*}{ LIQOIL } & $\mathrm{ADF}$ & $-1.261(-4.902)$ & \multirow{2}{*}{ Non-Stationary } & $\mathrm{ADF}$ & $-3.345(-5.569)$ & \multirow{2}{*}{ Non-Stationary } \\
\hline & $\mathrm{PP}$ & $-1.450(-4.902)$ & & $\mathrm{PP}$ & $-4.561(-5.120)$ & \\
\hline \multirow{2}{*}{ PETOIL } & $\mathrm{ADF}$ & $-5.301(-4.308)^{* * *}$ & \multirow{2}{*}{ Stationary } & $\mathrm{ADF}$ & $-3.102(-2.207)^{* * *}$ & \multirow{2}{*}{ Stationary } \\
\hline & PP & $-6.201(-5.308)^{* * *}$ & & PP & $-3.201(-1.723)^{* * *}$ & \\
\hline \multirow{2}{*}{ AGRI } & $\mathrm{ADF}$ & $-3.560(-2.781)^{* * *}$ & \multirow{2}{*}{ Stationary } & $\mathrm{ADF}$ & $-6.701(-3.618)^{* * *}$ & \multirow{2}{*}{ Stationary } \\
\hline & $\mathrm{PP}$ & $-3.601(-3.450)^{* * *}$ & & $\mathrm{PP}$ & $-5.135(-4.568)^{* * *}$ & \\
\hline \multirow{2}{*}{ MANU } & $\mathrm{ADF}$ & $-3.901(-3.450)^{* * *}$ & \multirow{2}{*}{ Stationary } & $\mathrm{ADF}$ & $-6.193(-4.568)^{* * *}$ & \multirow{2}{*}{ Stationary } \\
\hline & $\mathrm{PP}$ & $-5.902(-3.000)^{* * *}$ & & $\mathrm{PP}$ & $-6.150(-4.123) * * * *$ & \\
\hline \multirow{2}{*}{ SERV } & $\mathrm{ADF}$ & $-2.354(-3.349)$ & \multirow{2}{*}{ Non-Stationary } & $\mathrm{ADF}$ & $-6.451(-4.124)$ & \multirow{2}{*}{ Non-Stationary } \\
\hline & $\mathrm{PP}$ & $-3.458(-3.349)$ & & $\mathrm{PP}$ & $-5.431(-3.125)$ & \\
\hline
\end{tabular}
Clemente-Montanes-Reyes unit root test was employed to examine for unknown structural breaks in the series not captured by the ADF and PP unit root tests.

\begin{tabular}{|c|c|c|c|c|c|c|c|c|}
\hline \multirow[b]{3}{*}{ Variables } & \multicolumn{7}{|c|}{ Model: Trend-Break Model } & \\
\hline & \multicolumn{3}{|c|}{ Level data } & \multirow[b]{2}{*}{$\mathbf{K}$} & \multicolumn{4}{|c|}{ First difference data } \\
\hline & $\mathbf{T}_{\mathbf{B} 1}$ & $\mathbf{T}_{\mathrm{B} 2}$ & Test-statistics & & $\mathbf{T}_{\mathrm{B} 1}$ & $\mathbf{T}_{\mathrm{B} 2}$ & Test-statistics & $\mathbf{K}$ \\
\hline \multirow{2}{*}{ RGDP } & $2000 Q_{4}$ & - & -3.063 & 4 & $2003 Q_{4}$ & - & $-8.346^{* *}$ & 2 \\
\hline & $2000 Q_{4}$ & $2005 Q_{3}$ & -2.901 & 2 & $2003 Q_{4}$ & $2005 Q_{6}$ & $-6.730^{* *}$ & 8 \\
\hline \multirow{2}{*}{ ELECT } & $2005 Q_{1}$ & - & -2.350 & 2 & $2006 \mathrm{Q}_{6}$ & - & $-4.567 * *$ & 3 \\
\hline & $2007 Q_{3}$ & $2005 \mathrm{Q}_{5}$ & -3.890 & 3 & $2006 \mathrm{Q}_{4}$ & $2007 \mathrm{Q}_{1}$ & $-6.891 * *$ & 7 \\
\hline \multirow{2}{*}{ LIQOIL } & $2008 Q_{2}$ & - & -4.201 & 4 & $2009 \mathrm{Q}_{1}$ & - & $-6.461 *$ & 3 \\
\hline & $2009 Q_{1}$ & $2009 Q_{5}$ & -4.714 & 6 & $2009 Q_{3}$ & $2010 Q_{1}$ & $-5.781 * *$ & 5 \\
\hline \multirow{2}{*}{ PETOIL } & $2008 Q_{2}$ & - & -2.913 & 4 & $2010 Q_{5}$ & - & $-3.567 * *$ & 3 \\
\hline & $2009 Q_{2}$ & $2010 Q_{6}$ & -3.671 & 5 & $2010 \mathrm{Q}_{1}$ & $2010 Q_{4}$ & $-5.678^{* *}$ & 6 \\
\hline \multirow{2}{*}{ AGRI } & $2009 Q_{1}$ & - & -3.783 & 2 & $2009 \mathrm{Q}_{4}$ & - & $-2.345^{*}$ & 4 \\
\hline & $2010 Q_{2}$ & $2011 Q_{8}$ & -6.715 & 1 & $2009 \mathrm{Q}_{5}$ & $2011 \mathrm{Q}_{4}$ & $-4.567 * *$ & 8 \\
\hline \multirow{2}{*}{ MANU } & $2000 Q_{1}$ & & -4.871 & 3 & $2013 Q_{3}$ & - & $-6.567^{*}$ & 5 \\
\hline & $2006 Q_{3}$ & $2008 Q_{6}$ & -7.740 & 4 & $2013 Q_{5}$ & $2015 Q_{4}$ & $-7.891 *$ & 7 \\
\hline \multirow{2}{*}{ SERV } & $2016 Q_{1}$ & - & -2.893 & 3 & $2016 Q_{3}$ & - & $-5.123 * *$ & 4 \\
\hline & $2017 Q_{3}$ & $2018 Q_{3}$ & -7.491 & 4 & $2016 Q_{6}$ & $2017 Q_{3}$ & $-6.567^{*}$ & 6 \\
\hline
\end{tabular}

Table 3. ADF and PP Unit Test.

Note: The asterisks $* * *$ indicate significance at $5 \%$

Table 4. Clemente-Montanes-Reyes Structural Break Unit Root Analysis.

Note: $T_{B 1}$ and $T_{B 2}$ denote the period of structural breaks; $K$ lag length; $*$ and $* *$ significance at $1 \%$ and $5 \%$ levels, respectively. 
The Clemente-Montanes-Reyes unit root test results in a table (4) revealed the order of the variables of integration at first difference along with their structural breaks in the series from $2005 Q 3,2005 Q_{5}, 2007 Q_{1}$, $2008 Q_{5}, 2009 Q_{5}, 2010 Q_{1}, 2011 Q_{4}, 2015 Q_{4}, 2018 Q_{3}$, and $2017 Q_{3}$ respectively. The structural breaks in the series represent periods of economic decline and growth. In this regard, the energy sector reforms were initiated in 2005 to improve energy efficiency for economic growth. The 2007 pipeline vandalization grossly affected oil the economic, business, and financial activities in Nigeria. The 2008-2009 Niger Delta amnesty program for militants significantly influenced oil production and regional stability. The activities of Boko Haram in 2009 and farmers and herder's clashes in the North and middle of 2009 and 2017 significantly influenced the negative increase in food prices and business activities in the agricultural sector. The 2018 economic and financial recession in Nigeria grossly affected the growth of the industrial and service sectors in Nigeria.

\section{Test of Hypothesis}

$\mathbf{H}_{\mathbf{0}}$ : There is no co-integrating relationship between electricity consumption and sector value addition on economic growth in Nigeria.

$\mathbf{H}_{1}$ : There is a co-integrating relationship between electricity consumption and sector value addition on economic growth in Nigeria.

Table 5. ARDL Estimation

\begin{tabular}{|c|c|c|c|c|}
\hline \multicolumn{5}{|c|}{ Dependent Variable: ELECT } \\
\hline \multicolumn{5}{|l|}{ Method: ARDL } \\
\hline \multicolumn{5}{|c|}{ Selected Model: ARDL $(1,0,0,0)$} \\
\hline Variable & Coefficient & $\begin{array}{c}\text { Std. } \\
\text { Error }\end{array}$ & t-Stat & Prob.* \\
\hline ELECT(-1) & 0.875 & 0.057 & 15.256 & 0.000 \\
\hline LOGAGRI & -0.166 & 0.365 & -0.455 & 0.009 \\
\hline LOGMANU & 0.560 & 0.303 & 1.848 & 0.000 \\
\hline LOGSERV & -0.087 & 0.248 & -0.351 & 0.007 \\
\hline $\mathrm{C}$ & 0.218 & 4.307 & 0.050 & 0.959 \\
\hline R-squared & 0.90 & \multicolumn{2}{|c|}{ Durbin-Watson stat } & 1.934 \\
\hline F-statistic & 168.239 & \multicolumn{2}{|c|}{$\operatorname{Prob}(F$-statistic) } & 0.000 \\
\hline
\end{tabular}

Table (5) shows the ARDL results following the Pesaran, Shin, and Smith,[33] framework. The $\mathrm{R}^{2}$ shows the goodness of fit of the model of $90 \%$ accounting for an unexplained Variation of $10 \%$ explained by the independent variables. The F- statistic of (168.2398, a p-value of 0.000 ) at a critical value of $0.05 \%$ shows the significance and reliability of the model for meaningful analyses. The Durbin Watson Stat of (1.99) is approximately (2). There is no evidence of a first-order serial autocorrelation (AR(1). By rule of thumb, if the DW statistics is approximately (2), it is evidence against the existence of a first-order serial correlation.

Table 6. The ARDL Long-Run Result

\begin{tabular}{|c|c|c|c|c|}
\hline \multicolumn{5}{|l|}{ F-Bounds Test } \\
\hline Selected Model & \multicolumn{4}{|c|}{$(1,0,0,0)$} \\
\hline Test Statistics & Value & Signif. & $\mathrm{I}(0)$ & $\mathrm{I}(1)$ \\
\hline & \multicolumn{5}{|c|}{ Asymptotic $\mathrm{n}=1000$} \\
\hline F-statistics & 9.871 & $10 \%$ & 2.37 & 3.2 \\
\hline K & 3 & $5 \%$ & 2.79 & $3.67 * *$ \\
\hline & & $2.5 \%$ & 3.15 & 4.08 \\
\hline & & $1 \%$ & 3.65 & 4.66 \\
\hline
\end{tabular}

** at $5 \%$ significance level

Table 7. Error Correction Regression

\begin{tabular}{|c|c|c|c|c|}
\hline \multicolumn{4}{|l|}{ ARDL Error Correction Regression } \\
\hline \multicolumn{5}{|l|}{ Dependent Variable: D(LOGGDP) } \\
\hline Selected Model: ARDL(1, 0, 0, 0) \\
\hline Variable & Coefficient & Std. Error & t-Stat & Prob. \\
\hline CointEq (-1)* & -0.124954 & 0.039726 & -3.145379 & 0.0000 \\
\hline
\end{tabular}

Table (6) The bound test results shows that the F-statistic value of (9.871) is greater than the upper critical value of (3.67) and a lower bound critical value of (2.27) at a $0.05 \%$ p-level. The Bound test result confirms the presence of a long-run relationship between energy consumption, economic growth, and sectorial value addition in Nigeria.

Table (7) the CointEq(-1) of -0.12 and p-value of 0.000 shows the speed of convergence from disequilibrium cause in the short-run by energy supply-demand gap in production, distribution, and consumption, estimated billing system, vandalization, inadequate and poor energy sector infrastructure, frequent collapse of the national grip among others, back to a long-run equilibrium by $12 \%$.

The short-run results are substantiated by the results of Sharif, Jammazi, Raza, and., Shahzad [10]; Belaid, and Youssef, [8]; Adegboye and Babalola [16]; Harkat and Tahar [31] among others in Nigeria and other countries.

\section{Pairwise Granger Causality Test}

The granger causality was examined using the pairwise granger causality test. The test indicates that $\mathrm{x}$ causes $\mathrm{y}$ if the variable $\mathrm{x}$ increases the accuracy of the prediction of the variable y, and vice versa (Driouchi \& Harkat, [32]). 
Table 8. Granger Causality Test

\begin{tabular}{|c|c|c|c|c|}
\hline Null Hypothesis: & Obs & F-Statistic & Prob. & Decision \\
\hline LOGLIQOIL $\longrightarrow$ LOGGDP & 73 & 4.081 & 0.009 & causal relationship \\
\hline \multicolumn{2}{|l|}{ LOGGDP $\longrightarrow$ LOGLIQOIL } & 14.473 & 0.007 & causal relationship \\
\hline LOGPETOIL $\longrightarrow$ LOGGDP & 73 & 3.558 & 0.052 & No causal relationship \\
\hline \multicolumn{2}{|l|}{ LOGGDP $\longrightarrow$ LOGPETOIL } & 3.062 & 0.074 & causal relationship \\
\hline ELECT $\longrightarrow$ LOGGDP & 73 & 10.192 & 0.009 & causal relationship \\
\hline \multicolumn{2}{|l|}{ LOGGDP $\longrightarrow$ ELECT } & 18.0561 & 0.001 & causal relationship \\
\hline LOGAGRI $\longrightarrow$ ELECT & 73 & 1.344 & 0.474 & No causal relationship \\
\hline \multicolumn{2}{|l|}{ ELECT $\longrightarrow$ LOGAGRI } & 1.012 & 0.120 & No causal relationship \\
\hline LOGMANU $\longrightarrow$ ELECT & 73 & 9.766 & 0.0006 & causal relationship \\
\hline \multicolumn{2}{|l|}{ ELECT $\longrightarrow$ LOGMANU } & 4.334 & 0.0004 & causal relationship \\
\hline LOGSERV $\longrightarrow$ ELECT & 73 & 1.264 & 0.2937 & No causal relationship \\
\hline \multicolumn{2}{|l|}{ ELECT $\longrightarrow$ LOGSERV } & 0.111 & 0.9534 & No causal relationship \\
\hline
\end{tabular}

Table (8) the pairwise granger causality test revealed a two-way causality between energy consumption (natural gas), and economic growth, and economic growth to energy consumption (natural gas). The results support a bidirectional causality. A unit increase in natural gas and electricity consumption increases sectorial value addition proportionately on economic growth vis-visa sectorial value addition increasing the demand for natural gas and electricity consumption. Empirical evidence from Karanfil, [4]; Enu and Havi [1]; Ibrahiem [13]; Osman, Gachino, and Hoque [14]; Ahmad, Zhao, Shahbaz, Bano, Zhang, and Wang [15; Adegboye and Babalola [16]; Ibrahiem [17] Sarwar, Chen, and Waheed [18]; (Wang et al., [15] substantiated the findings of this study.

The result also revealed a one-way causality between economic growth and energy consumption (petroleum oil). The result supports a unidirectional causality. A unit increase in economic and sectorial value addition activities increases the demand for petroleum oil consumption for production and creativity. The findings of Molem, and Ndifor [6]); Chinedu, Daniel, and Ezekwe, [7]); Belaid, and Youssef [8]); Mawejje, and Mawejje [9]); Sharif, Jammazi, Raza, Shahzad, [10]); Laurine, Ngundu, and Kupeta [5]); Carfora, Pansini, and Scandurra, [11]) also substantiated the findings of this study.

On the other hand, a two-way causality was observed between electricity consumption and manufacturing sector value addition on economic growth. An increase in electricity supply increases the manufacturing sector value in addition to the economic growth effort of the government. Empirical evidence from Ibrahiem [17]
Sarwar, Chen, and Waheed [18]; (Wang et al., [15] also confirmed the findings of this study.

A non-causal relationship between energy consumption, sectorial value addition from the (service and agricultural sectors) on economic growth was observed. Aminu and Aminu, [19]; Bah, and Azam [20]; Egbichi, Ojamaliya, Okafor, Godwin, and Oluwapelumi [21], and Odhiambo, [22] confirm the findings of this study in their respective studies reported a non-causal relationship and supporting the neutrality hypothesis. Energy consumption and economic growth are not mutually dependent on each other.

\section{Conclusions}

Regardless of the sufficient empirical studies on the nexus between energy consumption and economic growth, there is still a lack of consensus on the directional causality among the variables. This study examines energy consumption and economic growth, extending the frontiers to cover the agricultural, manufacturing, and service sector's value addition, small business development on economic growth. Through the multivariate framework and fitted econometric techniques.

The Clemente-Montanes-Reyes unit root test was applied to check for unknown structural breaks in the series. This study differs from previous studies using predominantly the bivariate framework approach. To the best of our knowledge, no study in Nigeria has extended the frontiers of the study to accommodate the effect on the agricultural, manufacturing, small business, and service 
sectors value addition.

The findings of this study include

1. The Clemente-Montanes-Reyes unit root test reported the presence of structural breaks arising variables.

2. The co-integrating test results confirm the existence of long-run equilibrium relationships. This finding supports the feedback hypothesis in Nigeria.

3. The pairwise granger causality test also revealed a mix of results of a bidirectional causality; a unidirectional causality and a non-causal relationship.

In general, the study does not uphold the hypothesis of a neutral relationship between energy consumption and economic growth. Except for service and agricultural sector value addition. Inefficient energy supplies directly diminish the competitive prowess of the economic and non-economic indicators in stimulating economic growth and industrialization. Nigeria's energy problem is not a lack of sources of energy, but its development and utilization. Based on the findings, we, therefore, recommend the review of the estimated billing system to a more cost-effective and appropriate energy pricing framework to stimulate economic and business value addition.

\section{REFERENCES}

[1] Enu, P, Havi, E, D. Influence of Electricity Consumption On Economic Growth in Ghana: An Econometric Approach. International Journal of Economics, Commerce, and Management. 2 (9) pp1-20. 2014. https://doi.org/1.20/ijecm .2014 .10 .21

[2] The World Bank. World development indicators (WDI). The World Bank, Washington, DC (2019). https ://data.world bank. org/data.catal og/world -devel opmen t-indic actors.

[3] Central Bank of Nigeria. Statistical Bulletin, Vol. 22, December 2017.

[4] Karanfil, F., Li, Y. Electricity consumption and economic growth: exploring panel specific differences. Energy Policy 82, 264-277 (2015).https://doi.org/10.1016/j.enpol .2014.1 2.001 .

[5] Laurine, C., Ngundu, T., Kupeta, K., (2018). Economic Growth and Electricity Consumption in a Multivariate Framework: A Case of Zimbabwe 1980-2016. ACTA UNIVERSITATIS DANUBIUS. 14 (5) pp 20-34. 2018.

[6] Molem, C. S., Ndifor, F. T. The Effect of Energy of Consumption on Economic Growth in Cameroon. Asian Economic and Financial Review, 6 (9): 510-521, 2016. https://doi.org/9.9/efr.2016.510.521

[7] Chinedu, U. A., Daniel, O. C., Ezekwe, U. C. Impact of Energy Consumption on Economic Growth in Nigeria: An Approach to Time Series Econometric Model. International Journal of Academic Research in Economics and Management and Sciences, 8(2), 65-77, 2019. https ://doi.org/8.3/.2019.65-77.
[8] Belaid, F., Youssef, M. Environmental degradation, renewable, and non-renewable electricity consumption and economic growth: assessing the evidence from Algeria. Energy Policy 102, 277-287 (2017).https ://doi.org/10.101 6/j.enpol .2016.12.012

[9] Mawejje, J., Mawejje, D.N. Electricity consumption and sectoral output in Uganda: an empirical investigation. J. Econ. Struct. 5(21), 1-16 (2016). https ://doi.org/10.1186/s 4000 8-016-0053-8.

[10] Sharif, A., Jammazi, R., Raza, S.A., Shahzad, S.J.H. Electricity and growth nexus dynamics in Singapore: fresh insights based on wavelet approach. Energy Policy 110, 686-692 (2017). https://doi.org/10.1016/j.enpol .2017.07.0 29

[11] Carfora, A., Pansini, R. V., Scandurra, G. The causal relationship between energy consumption, energy prices, and economic growth in Asian developing countries: A replication. Energy Strategy Reviews, 23, 81-85. 2019 https: //doi. org/23.8/ESR .2019.81.85.

[12] Yu, E.S.H. \& Choi, J.Y. (1985). "The Causal Relationship between Energy and GNP: An International Comparison. Journal of Energy and Development, 10, 249-272.

[13] Ibrahiem, D.M (2015). Renewable electricity consumption, foreign direct investment, and economic growth in Egypt: an ARDL approach. Proc. Econ. Finance. 30, 313-323. https ://doi.org/10.1016/ S2212 -5671(15)01299-X

[14] Osman, M., Gachino, G., \& Hoque, A (2016).: Electricity consumption and economic growth in the GCC countries: panel data analysis. Energy Policy 98, 318-327 (2016). https ://doi.org/10.1016/j.enpol .2016.07.050

[15] Ahmad, A., Zhao, Y., Shahbaz, M., Bano, S., Zhang, Z., Wang, S., \& Liu, Y (2016).: Carbon emissions and economic growth: an aggregate and disaggregate analysis of the Indian economy. Energy Policy 96, 131-143 (2016). https ://doi.org/10.1016/j.enpol .2016.05.032.

[16] Adegboye, A, A, \& Babalola, I, B, (2017). Energy Consumption and Economic Growth Nexus: A Re-Examination of Causal Evidence in Nigeria. Journal of Applied Economics and Business Research JAEBR, 7(1): 19-37.https ://doi.org/10.1016/JAEBR/2017.19.03

[17] Ibrahiem, D., (2018). Investigating the causal relationship between electricity consumption and sectoral outputs: evidence from Egypt. Energy Transitions (2018) 2:31-48. https://doi.org/10.1016/.2018.02.048.

[18] Sarwar, S., Chen, W., Waheed, R. Electricity consumption, oil price, and economic growth: a global perspective. Renew. Sustain. Energy Rev. 76, 9-18 (2017).https ://doi.org/10.10 16/j.rser.2017.03.063

[19] Aminu, M. M., Aminu, M. F. Energy Consumption and Economic Growth in Nigeria: A Causality Analysis. Journal of Economics and Sustainable Development, 6, (13), pp42-53, 2015. https://doi. org/6.13/JESD.2015.42.053

[20] Bah, M.M., Azam, M. Investigating the relationship between electricity consumption and economic growth: evidence from South Africa. Renew. Sust. Energy Rev. 80, 531-537 (2017). https ://doi.org/10.1016/j.rser.2017.05.251.

[21] Egbichi, C, Ojamaliya, A, Okafor, V, Godwin, A., 
Oluwapelumi, A. Dynamic Impact of Energy Consumption on the Growth of Nigeria Economy (1986-2016): Evidence from Symmetrical Autoregressive Distributed Lag Model. International Journal of Energy Economics and Policy. 8(2), pp188-195, 2018. https ://doi.org/1.3 48./9098

[22] Odhiambo, N.M. Energy consumption and economic growth nexus in Tanzania: an ARDL bounds testing approach. Energy Policy, 37, 617-622. 2009.

[23] Babanyara, Y.Y, Saleh U. F. Urbanisation and the choice of fuelwood as a Source of Energy in Nigeria Journal of Human Ecology, 31(1) 19-26, 2010.https ://doi.org/JHE/31 $.148 . / 019-026$

[24] Aghion, P. Howitt, P. The Economics of Growth. MIT Press. Cambridge, MA.2009.

[25] Okorie D, \& Manu, S. Electricity Consumption and Economic Growth: The Nigerian Case. International Journal of Current Research. Vol. 8, Issue, 12, pp.44008-44017.2016 https ://doi.org/IJCR/8.1 48./019-026.

[26] Tahar, H. Causality between Energy Consumption and Economic Development: Empirical Evidence from Morocco. Munich Personal RePEc Archive 4 (7) 10-22.2020

[27] Sharaf, M.F. Energy consumption and economic growth in Egypt, a disaggregated causality analysis with structural breaks. The topical Middle East. African. Economic Journal. 18(2), 61-86. 2016. https ://doi.org/18.2/2016./61-086

[28] Ugwoke, T, I, Dike, C., Elekwa, P, O. Electricity Consumption and Industrial Production in Nigeria. Journal of Policy and Development Studies. 10, (2) pp 8-19. 2016. https ://doi.org/JPDS/010.2/8./019-026
[29] Dickey, D.A., Fuller, W.A. Distribution of the estimators for autoregressive time series with a unit root. J. Am. Stat. Assoc. 74(366), 427-431 (1979).

[30] Phillips, P.C., Perron, P. Testing for a unit root in time series regression. Biometrika 75(2), 335-346 (1988).

[31] Harkat, Tahar. The role of younger generations in economic, social, and political changes in Arab countries. International Journal of Energy. 7(6), 50-63 (2020). https://doi.org/IJE/3 $1.148 . / 019-026$

[32] Driouchi, A., Harkat, T. Granger causality and the factors underlying the role of younger generations in economic, social, and political changes in Arab countries. MPRA 77218.2017

[33] Pesaran, M., Shin, Y., Smith, R. Bounds testing approaches to the analysis of the level of relationship. Journal of Applied Econometrics, 16, pp 236-289.2001.

[34] Stern, D. I. "Is Energy Cost an Accurate Indicator of Natural Resource Quality?”. Economics and Policy. 8(2), pp188-195.1999. https ://doi.org/10.22863 48

[35] Ghosh, S.: Electricity consumption and economic growth in India. Energy Policy 30, 125-129 (2002)

[36] Halicioglu, F.: Residential electricity demand dynamics in Turkey. Energy Econ. 29(2), 199-210 (2007). https ://doi.org/10.1016/j. eneco .2006 .11 .007

[37] Nathan, T.M., Liew, V.K.: Does electricity consumption have significant impact towards the sectoral growth of Cambodia? Evidence from Wald test causality relationship. J. Empir. Econ. 1(2),59-66 (2013) 